\title{
Reproductive Biology of the Mola Carplet Amblypharyngodon mola (Hamilton) (Cypriniformes: Cyprinidae) from Netrakona Water
}

\author{
Bimal Kanta Saha*a, M. Rafiqul Islam ${ }^{\mathrm{a}}$, Aparna Saha ${ }^{\mathrm{a}}$ and M. Altaf Hossain ${ }^{\mathrm{b}}$ \\ ${ }^{a}$ Department of Zoology, Netrakona Govt. College, Netrakona-2400, Bangladesh and. ${ }^{b}$ Department of Zoology, \\ Rajshahi University, Rajshahi, Bangladesh.
}

\begin{abstract}
Some aspects of the reproductive biology viz. sex ratio, fecundity and reproductive periodicity of Amblypharyngodon mola were studied during March 2004 through February 2005 in Netrakona. Sex ratio was found to be 1:2.03. Fecundity varied from 1,291 to 12,797 with a mean value 5,751.46 \pm 3,321.73 eggs. The relationships between Fecundity (F) and Total Length (TL), Standard Length (SL), Total Weight (TW), Gonadal length (GL) and Gonadal Weight (GW) were calculated and found to be highly significant. The mean of ova diameter was $1.4 \pm 0.35 \mathrm{~mm}$. Different methods used to study the reproductive periodicity showed that the periodicity of A. mola starts from March and continues up to August with a peak in May.
\end{abstract}

Key words : Reproductive biology, Reproductive periodicity, Amblypharyngodon mola.

\section{Introduction}

Among the fishery items, the small fishes occupy an important position in the popular food items. Some of the small fishes have high nutritional value as they contain protein, vitamin A, iron, calcium, phosphorus etc. (Banu et al., 1985).

The mola carplet or pale carplet, Amblypharyngodon mola (Hamilton) is locally known as Moa, Mowka, Moraru, Mouchi, Mowrala, Mola, Moya, or Molongi. The mola carplet is found to occur in the rivers, streams, ponds, ditches, beels, baors, tanks and inundated fields throughout Bangladsh. The species is distributed in India, Pakistan and Myanmar (Bhuiyan, 1964). The fish contains high protein, vitamin A and minerals and can be eaten wholly with bones.

Works on sex ratio and fecundity of different fishes have been done by Afroze and Hossain (1983) and Sultana (1991).

Experiments on reproductive cycle of freshwater fishes have been carried out by different workers (Afroze and Hossain, 1990 and Latifa and Nahar, 1987). It is evident that like other population of fishes, $A$. mola is on the decrease due to natural and other factors. A study of the reproductive biology of $A$. mola appears essential in the sense that it may provide information and clues for a tactful and skilful culture and fishing of this species. No work has been done on reproductive biology of $A$. mola from Netrakona waters.
Therefore, the objective of the present experiment was to determine the sex ratio, fecundity and reproductive periodicity of $A$. mola from Netrakona water.

\section{Materials and Method}

A total of 358 specimens of A mola was collected during March 2004 to February 2005 from three fish markets viz. Rail crossing bazar, Machh bazar and Ghoser bazar of Netrakona town. After collection, the specimens were preserved in 5\% formalin. The total length and standard length of the fishes were measured in the nearest mm by means of a measuring board fitted with a centimeter scale and their weights were recorded by means of a sensitive 'Pan balance' (Industrial balance model TG 928A, capacity 200g sensitivity 10mg, Serial no. 9510, China). The ovaries of the female fish were removed, dehydrated and their weights were taken. The colouration of the gonads was observed throughout the year. The reproductive periodicity of $A$. mola was determined by using the following five methods:

I Percentage of gravid females against time;

II Gonado-Somatic Index (GSI);

III Gonadal-Length Index (GLI);

IV Diameter of ova (DO) and

V Colouration of ovary.

\footnotetext{
* Corresponding author:
} 
The Gonado-Somatic and Gonadal-Length Indices were calculated using the following formulae (Jhingran 1961 and Kader et al.1988):

$$
\begin{aligned}
& \text { GSI }=\frac{\text { Weight of the goand }}{\text { Weight of the body }} \times 100 \text { and } \\
& \text { GLI }=\frac{\text { Length of the goand }}{\text { Length of the body }} \times 100
\end{aligned}
$$

10 to 15 ova were collected at random from the anterior, central and posterior regions of each ovarian lobe of a specimen, Diameter of the collected ova was measured with the help of an ocular micrometer (each division being equivalent $0.01 \mathrm{~mm}$ ). The gonadal length and breadth were measured by means of a measuring board with the help of a fine point divider and gonadal weight was taken by using sensitive 'Pan Balance'. Gravimetric method (Lagler, 1956) was used to determine the fecundity.

\section{Results and Discussion}

\section{Sex ratio :}

Out of 358 specimens of $A$. mola, 118 were male and 240 were female. The male and female ratios were $1: 2.03$. The monthwise percentages of males and females showed that the females were predominant throughout the year. Latifa and Nahar (1987) obtained the sex ratio of Puntius chola as
2:3. Sultana (1991) recorded the sex ratio of Aspidoparia morar as 1:1.42. Afroze and Hossain (1983) recorded the sex ratio of $A$. mola as $1: 1.67$.

\section{Fecundity :}

During the estimation of the fecundity of $A$. mola, it was found that the number of eggs varied from 1,291 (total length $48.00 \mathrm{~mm}$ and total weight $1.4 \mathrm{~g}$ ) to 12,737 (Total length $82.00 \mathrm{~mm}$ and total weight $5.9 \mathrm{~g})$. The mean fecundity was 5,751.73 $\pm 3,321.73$ eggs for mean total length of $62.73 \pm 7.39 \mathrm{~mm}$ and mean total weight of $2.67 \pm 2.73 \mathrm{~g}$. It was observed in the experiment that the same sized fish had different number of eggs in their ovaries. Such type of variation was also common in other fishes (Islam and Hossain 1990). Afroze and Hossain (1983) observed the mean fecundity of A. mola as 3,596 \pm 150.46 and Parveen (1984) as 3601.

\section{Breeding periodicity :}

I. Percentage of gravid females against time : Occurrence of higher percentage of gravid females were noted during March to August. The highest percentage of gravid females was recorded in May and August (Table 1I).

II. Gonado-Somatic Index (GSI) : Higher mean values of GSI were recorded from March to August with a peak value in May as 16.46 (Table I).

\begin{tabular}{|c|c|c|c|c|c|c|c|c|}
\hline \multirow{2}{*}{$\begin{array}{l}\text { Year } \\
\text { Month }\end{array}$} & \multirow{2}{*}{$\begin{array}{c}\text { Percentage } \\
\text { of gravid } \\
\text { females }\end{array}$} & \multicolumn{2}{|c|}{ GLI } & \multicolumn{2}{|c|}{ GSI } & \multicolumn{2}{|c|}{$\mathrm{OD}(\mathrm{mm})$} & \multirow[b]{2}{*}{$\begin{array}{l}\text { Colour of } \\
\text { ovary }\end{array}$} \\
\hline & & $\begin{array}{l}\text { Range } \\
\text { Minimum } \\
\text { Maximum }\end{array}$ & Mean & \begin{tabular}{|l|} 
Range \\
Minimum \\
Maximum \\
\end{tabular} & Mean & $\begin{array}{l}\text { Range } \\
\text { Minimum } \\
\text { Maximum }\end{array}$ & Mean & \\
\hline 2004 Mar & 80.00 & $26.31-30.00$ & $27.79 \pm 1.31$ & 8.0-14.34 & $12.47 \pm 3.0$ & $0.98-1.93$ & $1.64+0.21$ & Yellow \\
\hline 2004 Apr & 57.50 & 25.25-33.33 & $28.40 \pm 5.46$ & $9.07-18.0$ & $14.79 \pm 2.60$ & $1.02-2.18$ & $1.71 \pm 0.22$ & Yellow orange \\
\hline 2004 May & 100.00 & $24.59-34.48$ & $29.44 \pm 2.14$ & $10.86-20.11$ & $16.46 \pm 9.65$ & $1.1-1.94$ & $1.27 \pm 0.14$ & Orange \\
\hline 2004 Jun & 90.00 & $22.22-33.33$ & $27.98 \pm 2.95$ & $10.0-19.56$ & $15.16 \pm 1.40$ & $1.1-2.27$ & $1.82 \pm 0.43$ & Orange \\
\hline 2004 Jul & 85.70 & 20.33-29.61 & $26.23 \pm 3.94$ & 7.38-19.09 & $12.21 \pm 2.77$ & $0.90-2.08$ & $1.71 \pm 0.30$ & Orange \\
\hline 2004 Aug & 100.00 & $19.76-29.85$ & $24.76+2.90$ & $6.13-17.18$ & $10.37 \pm 5.22$ & $0.85-2.0$ & $1.56+0.56$ & Yellow orange \\
\hline 2004 Sep & 25.00 & $15.25-27.69$ & $21.69+4.56$ & $3.12-16.52$ & $7.87 \pm 1.81$ & $0.64-1.74$ & $1.44 \pm 0.32$ & Yellow \\
\hline 2004 Oct & 40.00 & $14.81-27.58$ & $22.34+5.04$ & 2.11-15.98 & $6.90 \pm 3.01$ & $0.43-1.68$ & $1.05 \pm 0.24$ & Yellowish \\
\hline 2004 Nov & 50.00 & $14.58-25.42$ & $20.96 \pm 3.77$ & $0.9-14.34$ & $5.27 \pm 2.17$ & $0.15-1.07$ & $0.68 \pm 0.61$ & Light brown \\
\hline 2004 Dec & 50.00 & $15.78-28.33$ & $23.13 \pm 4.79$ & $1.6-16.5$ & $8.9+4.71$ & $0.26-1.23$ & $1.09 \pm 0.38$ & Yellow orange \\
\hline 2005 Jan & 30.00 & $16.17-29.68$ & $23.69 \pm 4.42$ & $3.32-17.02$ & $9.43 \pm 1.18$ & $0.3-1.80$ & $1.09 \pm 0.55$ & Light brown \\
\hline 2005 Feb & 72.72 & 23.07-31.51 & $26.60 \pm 9.62$ & $4.76-17.14$ & $10.11 \pm 1.89$ & $0.6-1.91$ & $1.48 \pm 0.37$ & Yellow \\
\hline Overall & $65.02 \pm 25.36$ & & $25.25 \pm 2.75$ & & $10.83 \pm 3.32$ & & $1.38 \pm 0.33$ & \\
\hline
\end{tabular}

Table I. Monthly percentage of gravid females, GLI, GSI, OD and colour of ovary of Amblypharyngodon mola. 
III. Gonadal-Length Index (GLI) : The higher mean values of GLI were recorded in February to August with a peak mean value in May as 29.44 (Table I).

IV. Diameter of Ova (OD): The maximum mean diameters of ova were obtained in March to August with a peak mean value in June as $1.82 \mathrm{~mm}$ (Table I).

V. Colouration of the Ovary : The ovaries were observed to change from light brown to orange in colour. The ovaries of most females collected in May to July were orange in colour.

According to Afroze and Hossain (1990), August was the peak breeding season of A. mola. Parveen (1984) stated that the breeding season of $A$. mola was from June to October/November.

\section{References}

Afroze S., and Hossain M. A. (1983) The fecundity and sex ratio of Amblypharyngodon mola (Ham.) (Cypriniformes : Cyprinidae). Univ. J. Zool. Rajshahi Univ. 2: 29-32.

Afroze S. and Hossain M. A. (1990) The reproductive cycle of the freshwater fish Amblypharyngodon mola (Ham.) (Cypriniformes : Cyprinidae). Univ. J. Zool. Rajshahi Univ. 9:17-21.

Banu N., Ali S., Saha T. R. and Vakta N. C. (1985) The studies on the fecundity of Anabas testudineus (Bloch) in a confined pond of Dhaka district. Bangladesh $J$. Aquaculture, 6-7 (I): 45-49.
Bhuiyan A. L. (1964) Fishes of Dacca. Asiatic Society of Pakistan, Dacca, 148 pp.

Islam M. S. and Hossain M. A. (1990) The fecundity and sex ratio of the common punti, Puntius stigma (Cypriniformes : Cyprinidae). Univ. J. Zool. Rajshahi Univ., 9: 69-74.

Jhingran A. G. (1961) Studies on the maturity and fecundity of the Gangetic anchovy, Setipinna phasa (Hamilton). Indian J.Fish., 8: 291-312.

Kader M. A., Bhuiyan A. L. and Manzur-I-Khuda, A. R. M. M. (1988) The reproductive biology of Gobioides rubicundus (Ham.Buch.) in the Karnafuli river estuary, Chittagong. Indian J.Fish., 35:139-250.

Lagler K. F. (1956) Enumeration of fishes eggs. In Freshwater fishery biology, 2nd edition, W.M. Brown Company Publishers, Dubuque, 106-116.

Latifa G. A. and Nahar L. (1987) Some aspects of biology of Punitus stigma. Bangladesh J. Zool., 15(1): 51-58.

Parveen S. (1984) Studies on the culture methods and some aspects of the biology of Amblypharyngodon mola. M.Sc. Thesis, Department of Zoology, Rajshahi University 137pp.

Sultana N. (1991) Some aspects of biology of Aspidoparia morar (Hamilton) (Cypriniformes : Cyprinidae). M.Sc. Thesis, Department of Zoology, Rajshahi University, Rajshahi.

Received : February 06, 2008;

Accepted : April 27, 2009 